Int. Archs Allergy appl. Immun. 1984;74:I-IV

\title{
Contents, Vol. 74, 1984
}

Vol. 74, 1984

International Archives

of Allergy and Applied

Immunology

Founded 1950 by D. Harley, P. Kallós, W. Löffler and F.W. Wittich Continued by E.A. Brown

(1952-1954), W. Kaufman (1955-1967), F. Hahn (1961-1972) and H.C. Goodman (1963-1975)

Editors-in-Chief

R.R.A. Coombs, Cambridge L.Å. Hanson, Göteborg P. Kallós, Helsíngborg F. Milgrom,

Buffalo, N.Y. Z. Trnka. Basel G.B. West, Epsom

Contributing Editors

C.J. Abeyounis, Buffalo, N.Y.

N.F. Adkinson, Jr., Baltimore, Md.

B. Albini, Buffalo, N.Y.

G. Andres, Buffalo, N.Y.

E.L. Becker, Farmington, Conn.

L. Belin, Göteborg

W.E. Brocklehurst, Windlesham

A. Capron, Lille

A. Cerletti, Basel

C.G. Cochrane, La Jolla, Calif.

B. Diamant, Copenhagen

P. Dukor, Basel

L. Edebo, Göteborg

W.P. Faulk, Charleston, S.C.

P.G.H. Gell, Birmingham

I. Glazer, Tel Aviv

R.A. Good, Oklahoma City, Okla.

M. Hess, Bern

L. Hudson, Beckenham

H. Isliker, Lausanne

S.G.O. Johansson, Stockholm

E.A. Kabat, New York, N.Y.

K. Kano, Tokyo

W. Müller-Ruchholtz, Kiel

F. Ørskov, Copenhagen

Ö. Ouchterlony, Göteborg

Z. Ovary, New York, N.Y. 


\author{
P. Perlmann, Stockholm \\ E. Pick, Tel Aviv \\ M. Plaut, Baltimore, Md. R.E. Reisman, Buffalo, N.Y. \\ G. Riethmüller, München \\ M. Roitt, London \\ K. Rother, Heidelberg \\ G. Sandberg, Stockholm \\ H.D. Schlumberger, Wuppertal \\ K.H. Schulz, Hamburg \\ A. Sehon, Winnipeg \\ O. Strannegård, Göteborg \\ A. Szentivanyi, Tampa, Fla. \\ O. Tönder, Bergen \\ G. Torrigiani, Geneve \\ J.L. Turk, London \\ E.R. Unanue, Boston, Mass. \\ B.H. Waksman, New York, N.Y. \\ G. Wick, Innsbruck \\ $\mathrm{mm}$ \\ Contents Vol. 74,1984 \\ No. 1 \\ Original Paper \\ Sequential Changes of the Five Immunoglobulin Classes and \\ Other Responses in Infectious Mononucleosis \\ Bahna, S.L.; Heiner, D.C.; Horwitz, C.A 1 \\ Effect of Cyclic AMP-Elevating Agents on Human Sponta \\ neous IgE Synthesis in vitro \\ Strannegård, Ö.; Strannegård, I.-L 9 \\ Comparative Actions of Biologic and Synthetic Leukotrienes \\ on Isolated Human Bronchus and Rat Mast Cells \\ Hanna, C.J.; Johnston, M.E.; Bach, M.K.; Rokach, J.; \\ Schellenberg, R.R 15 \\ Streptococcal Preparation OK-432-Induced Interferon in $\mathrm{Hu}$ \\ man Leukocytes: Purification and Characterization \\ De Ley, M.; Claeys, H \\ 21 \\ Platelet Augmentation of IgE-Dependent Histamine Release \\ from Human Basophils and Mast Cells \\ Knauer, K.A.; Kagey-Sobotka, A.; Adkinson. N.F., Jr.; \\ Lichtenstein. L.M 29 \\ Polyethylene Glycol Reactive Antibodies in Man: Titer Distri \\ bution in Allergic Patients Treated with Monomethoxy \\ Polyethylene Glycol Modified Allergens or Placebo, and in \\ Healthy Blood Donors \\ Richter, A.W.; Åkerblom. E 36
}


Migration of Blood-Borne Lymphocytes into Antigen-Stimulated Lymph Nodes. A Study of the Kinetics of Lymphocyte Recruitment throughout an Immune Response Kimpton. W.G.: Walsh, A.; Poskitt. D.C.; Muller, H.K. . 40

Distribution of Membrane-Associated Actin in Sheep Lympho

cytes. Functional Implications

Mèly-Goubert, B.; Dudler, L.; Miyasaka. M 45

Immunoglobulin $\mathrm{E}$ in Extracts of Feces from Children

Kolmannskog, S.; Haneberg, B.; Marhaug, G.; Bolle, R. . 50

Comparative Studies on Tree Pollen Allergens. VII. Monome

thoxy Polyethylene Glycol Conjugation of the Major Aller

gen of Birch Pollen (Betula verrucosa)

Vik, H.; Sørnes, S,; Elsayed, S 55

Immune Complexes in Ovarian Cancer: Association between IgM Class Complexes and

Antinuclear Autoantibodies in Ascitic Fluid

Silburn, P.A.; Neil, J.C.; Khoo, S.K.: Daunter, B.; Hill, R.;

Collins, R.J.; Mackay, E.V 63

Distribution of Cat Allergen 1 in Cat Tissues and Fluids

Brown, P.R.; Leitermann, K.; Ohman, J.L.. Jr

67

In vitro Studies Involving Histamine and Lysosomal Enzyme

Release from Human Peripheral Leukocytes with Different

Human Serum Albumin (HSA) Preparations

Ring, J 71

Age-Dependent Changes of the Fc $\gamma$-Receptor-Mediated Func

tions of Human Monocytes

Fülöp, T.; Fóris, G.; Wórum, I.; Leövey, A 76

Effects of Phenytoin and Carbamazepine on Subpopulations of

Mononuclear Blood Cells as Defined by Membrane Anti

gens

Gilhus, N.E $\quad 80$

Use of a Simple in vivo Technique to Investigate Components

of the Immediate Hypersensitivity Reaction in Conscious

Guinea Pigs

Hammerbeck. D.M.; Swingle. K.F 84

Short Communications

Mouse Ear PCA as a Model for Evaluating Antianaphylactic

Agents

Inagaki, N.; Goto. S.: Nagai, H.; Koda, A 91

Mixed Passive Hemagglutination with Soluble Platelet Antigens

Shibata, Y.; Juji, T.; Tohyama, H.; Sakamoto, H.; Ozawa,

N.; Kano, K 93

No. 2

Original Paper

Suppression of Mixed Lymphocyte Culture by Uremic Adher ent Spleen Cells and Peritoneal Macrophages Is Dependent

on a Cyclophosphamide-Sensitive Cell

Alevy. Y.G.; Mueller, K.R.; Slavin, R.G 
Effect of the Calcium Ionophore A23187 and Aspirin on Histamine Release in vitro from Leukocytes of Aspirin-Intolerant Donors Bochner, B.S.; Thomas, L.L.; Godnik, L.; Samter, M. . .104

Failure of Covalently Cross-Linked Human IgG Myeloma Subclass Protein to Release Histamine from Human Leukocytes Zhou. T,; Conroy, M.C.; Spengler, H.; Week, A.L. de . . 108

Sidedness of the Reaction to ß-Lactoglobulin in Sensitised

Colonic Epithelia

Kessel, D.: Cuthbert. A.W 113

Transduction of Effector-Suppressor T Cells by an Antigen-Specific Suppressor T Cell Factor and Lyt-1+,2+,3+ T Cells Tokuhisa. T.; Okumura, K.; Taniguchi. M.; Tada, T. . . 120

Immunogenicity of a Hapten-Carrier Conjugate Taken up by

Peritoneal Cells

Neveu, P.J 126

Suppression of IgE Antibody Response by Preadministration of Antigen-Pulsed Spleen Cells. II. Characteristics of Immediate Tolerance Induction Kojima, N.; Mabuchi, A.; Yokomuro, K.;

Kimura, Y. . 132

Lymphocyte-Induced Macrophage Cytotoxicity. Production of

Specific Macrophage Arming Factor by Sensitized Lyt 1+2+

T-Lymphocytes

Pels, E.; De Wegcr, R.A.; Den Otter, W 140

Contents

III

Studies on C3ahU Binding to Human Eosinophils: Characterization of Binding

Goers, J.W.; Glovsky, M.M.; Hunkapiller, M.W.; Farns-

worth, V.; Richards, J.H 147

Studies on the Binding of Complement Factor C4 in Human

Platelet. Complement Activation by Means of Cold Agglu-

tinins

Sandvik, T.; Endresen, G.K.M.; Førre, 0152

Vernal Keratoconjunctivitis: The Significance of Immunoglob-ulin E Levels in Tears and Serum Samra, Z.; Zavaro, A.; Barishak, Y.; Sompolinsky, D. . 158

Intestinal Mast Cell Changes in Guinea Pigs Infected with the

Nematode Trichostrongylus colubriformis

Handlinger, J.H.; Rothwell, T.L.W 165

Kinetics of the Histological Changes in Lymphoid Organs and

of the T-Cell Inducing Capacity of Serum in Mice Treated

with Imuthiol ${ }^{\circledR}$ (Sodium Diethyldithiocarbamate)

Pompidou, A.; Renoux, M.; Guillaumin, J.-M.; Macé, B.;

Michel, P.; Coutance, F.; Renoux, G 172

The Micro vasculature of the Hamster Cheek Pouch as a Model

for Studying Acute Immune-Complex-Induced Inflamma

tory Reactions (with 1 color plate)

Björk, J.; Smedegård, G 178 
Recruitment of Thymocytes from Gl into S Phase by a Thymic

Factor

Söder, O.; Ernström, U 186

No. 3

Original Paper

Induction of Long-Term Heart Allograft Survival in the Rat by

Rabbit ATG

Mjörnstedt, L.; Olausson, M.; Hedman, L.; Lindholm, L.;

Brynger, $\mathrm{H} \quad 193$

Leukocyte Sensitization against Synovial Components in

Rheumatoid Arthritis: Blocking by Pregnancy Serum

Appelboom, T.; Persellin, R.H 200

Age-Associated Changes of the Characteristics of Autoanti-

body-Forming Cells in NZB/W Mice

Terada, E.; Okudaira, H.; Ghoda, A.; Miyamoto, T. ... 206 Granulocyte Migration Abnormality in Patients Suffering from

Seasonal Allergic Rhinitis: Failure of Treatment with

Cimetidine

Maderazo, E.G.; Albano, S.D 211

Proliferation of Mouse Lymphocytes to Rye Grass Pollen Extract: Effect of Inflammatory

Exudate Cells

Cook, R.M.; Moran, D.M 216

Intestinal Resistance to Cholera Toxin in Mouse. Antitoxic

Antibodies and Desensitization of Adenylate Cyclase

Lange, S.; Lönnroth, I.; Nygren, H 221

Studies on Cholera-Toxin-Induced Desensitization of Adenylate Cyclase in the Mouse Intestinal

Mucosa

Lönnroth, I.; Lange, S.; Hansson, H.-A 226

Adjuvant and Immunogenic Properties of Gonococcal R-Type

Lipopolysaccharide in Reaginic Antibody Formation in

Mice

Vijay, H.M.; Ashton, F.E.; Diena, B.B 232

Cross-Reactivity of IgE Antibodies with Allergens in Birch Pollen, Fruits and Vegetables

Halmepuro, L.; Vuontela, K.; Kalimo, K.; Björkstén, F. . 235

Cellular Immunity in Renal Failure: Depression of Lympho

cyte Transformation by Uraemia and Methylprednisolone.

Intra-Individual Consistency of Lymphocyte Responses to

the in vitro Suppressive Effect of Steroid

Langhoff, E.; Ladefoged, J 241

Isotype IgE Class-Specific Suppression in the Biozzi 'High' and

'Low' Lines of Mice

Hirano, T.; Mouton, D.; Biozzi, G.; Ovary, Z 246

IgA Antibody Produced by Local Presentation of Antigen in

Orally Primed Rats

Cox, D.S.; Muench, D249 
Studies on Alternaria Allergens. IV. Comparative Biochemical and Immunological Studies of Commercial Alternaria tennis Batches Vijay, H.M.; Huang, H.; Young, N.M.; Bernstein, I.L. . . 256

IgG Antibodies to Purified Aspergillus fumigatus Antigens De termined by Enzyme-Linked Immunosorbent Assay

Schønheyder, H.; Andersen, P 262

Origins of Serum IgE and of the Homocytotropic Antibody-

Secreting Cells in the Thoracic Duct Lymph of Rats Infested

with Nippostrongylus brasiliensis

Allan, W.; Mayrhofer, G 270

Influence of Naturally Occurring Human Immune Complexes on Monocyte Movement in vitro

Batten, S.; Aggarwal, R.; Cockerell, R.; Tanner, A.R. ... 274

Short Communications

Histamine Release from Mast Cells of the Rat

West, G.B 278

Differentiation of Ovine Immature B Cells upon Exposure to

Phorbol Myristate Acetate

Miyasaka, M.; Dudler, L

281

First Case of Acquired Functional CÎ INH Deficiency:

Association with Angioedema during Churg and Strauss

Vasculitis

Pasquali, J.-L.; Christmann, D.; Modert, F.; Belval, P.C.;

Storck, D.; Hauptmann, G 284

Antibody-Dependent Cell-Mediated Cytotoxicity against

HLA-A, HLA-B and HLA-DR Specificities

Akiyama, N.; Ohsawa, N.; Kano, K 286

No. 4

Original Paper

Regulation of Allotype-Linked NPb Idiotype by an Idiotype-

Positive Soluble Factor Derived from a T Cell Hybrido-

ma. Coupling of the Circuit Regulation to the Network

Concept

Abe, R.; Karasuyama, H.; Yagi, J.; Tada, T 289

Studies on Thymocyte Subpopulations in Guinea Pigs. V. Ro

sette Formation as a Tool to Separate Thymocyte Growth

Factor Responsive and Mitogen Reactive Cells

Sandberg, G.; Söder, $0 \quad 297$

IV

Contents

Regulation of Constitutive Bone Marrow Cell Proliferation by

Bone Marrow Suppressor Cells

Soderberg, L.S.F 305

Kinetics of Intestinal Lamina propria Mast Cells, Globule Leucocytes, Intraepithelial

Lymphocytes, Goblet Cells and Eo-sinophils in Murine Strongyloidiasis Carroll, S.M.;

Mayrhofer, G; Dawkins, H.J.S.; Grove, D.I. 311 
Identification and Characterization of Parietaria judaica Aller

gens

Corbi, A.L.; Carreira, J 318

Non-Cytotoxic Alloantibodies Defined by the EA Rosette Inhibition Assay

Mason, R.J.; Macleod, A.M.; Power, D.A.; Stewart, K.N.;

Shewan, G.; Catto, G.R.D 324

Suppression of the IgE Antibody Response by Glutaraldehyde-

Modified Ovalbumin: Dissociation between Loss of Anti-

genic Reactivity and Ability to Induce Suppression

HayGlass, K.T.; Strejan, G.H 332

Differential Activities of Rabbit Bone Marrow Suppressor

Cells

Soderberg, L.S.F 341

Platelets and Bronchospasm

Page, C.P.; Paul, W.; Morley, J 347

A Method for Measuring Changes in Tracheal Mucus Gel Layer

Thickness as an Indication of an Immediate Hypersensitiv-

ity Response

Yanni, J.M.; Smith, W.L.; Callaham, E.M.; Foxwell, M.H.;

Alphin, R.S 351

Inhibition of IgE-Mediated Histamine Release from Human

Basophils and Mast Cells by Fenoterol

Marone, G.; Ambrosio, G.; Bonaduce, D.; Genovese, A.;

Triggiani, M.; Condorelli, M 356

Inhibition of Antigen- and Calcium Ionophore A23187-In-

duced Contractions of Guinea Pig Isolated Airways with

8-(Diethylamino)Octyl-3,4,5-Trimehtoxybenzoate Hydro-

chloride(TMB-8)

Burka, J.F 362

Demonstration of Long-Lived Memory T Suppressor Cells in

the IgE Response

HayGlass, K.T.; Strejan, G.H 365

Adjuvant Requirements for Protective Immunization of Mice

Using a Trypanosoma cruzi 90K Cell Surface Glycoprotein

Scott, M.T.; Bahr, G.: Moddaber, F.; Afchain, D.; Chedid, L. 373

Book Reviews $\quad 378$

Author Index 379

S. Karger $\cdot$ Medical and Scientific Publishers $\cdot$ Basel

- München $\cdot$ Pans $\cdot$ London $\cdot$ New York $\cdot$ Tokyo - Sydney

Drug Dosage

The authors and the publisher have exerted every effort to ensure that drug selection and dosage set forth in this text are in accord with current recommendations and practice at the time of publication. However, in view of ongoing research, changes in government regulations, and the constant flow of information relating to drug therapy and drug reactions, the reader is urged to 
check the package insert for each drug for any change in indications and dosage and for added warnings and precautions. This is particularly important when the recommended agent is a new and/or infrequently employed drug.

All rights reserved.

No part of this publication may be translated into other languages, reproduced or utilized in any form or by any means, electronic or mechanical, including photocopying, recording,

microcopying, or by any information storage and retrieval system, without permission in writing from the publisher or, in the case of photocopying, direct payment of a specified fee to the Copyright Clearance Center (see 'Information for Readers and Subscribers').

(C) Copyright 1984 by

S. Karger AG, P.O. Box, CH-4009 Basel (Switzerland)

Printed in Switzerland by Buchdruckereí Basler-Zeitung AG, Basel 